\title{
Dependence of radon levels in Postojna Cave on outside air temperature
}

\author{
A. Gregorič, A. Zidanšek, and J. Vaupotič \\ Jožef Stefan Institute, Ljubljana, Slovenia \\ Received: 20 December 2010 - Revised: 20 April 2011 - Accepted: 21 April 2011 - Published: 23 May 2011
}

\begin{abstract}
Postojna Cave is the largest of 21 show caves in Slovenia. The radon concentration there was measured continuously in the Great Mountain hall from July 2005 to October 2009 and ranged from about $200 \mathrm{~Bq} \mathrm{~m}^{-3}$ in winter to about $3 \mathrm{kBq} \mathrm{m}^{-3}$ in summer. The observed seasonal pattern of radon concentration is governed by air movement due to the difference in external and internal air densities, controlled mainly by air temperature. The cave behaves as a large chimney and in the cold period, the warmer cave air is released vertically through cracks and fissures to the colder outside atmosphere, enabling the inflow of fresh air with low radon levels. In summer the ventilation is minimal or reversed and the air flows from the higher to the lower openings of the cave. Our calculations have shown that the effect of the difference between outside and cave air temperatures on radon concentration is delayed for four days, presumably because of the distance of the measurement point from the lower entrance (ca. $2 \mathrm{~km}$ ). A model developed for predicting radon concentration on the basis of outside air temperature has been checked and found to be successful.
\end{abstract}

\section{Introduction}

Radon $\left({ }^{222} \mathrm{Rn}\right)$, a radioactive gas with a half-life of 3.82 days, is released from minerals into the pore space of rocks and subsequently into the atmosphere (Nazaroff, 1992). It is well known that high concentrations of radon are common in mines (Cohen, 1982; Sevc et al., 1976). The existence of similar radiation in underground cavities was found in the 1970s, since when research on radon concentration in natural caves has taken two directions. The first is the aspect of radiation protection (Duenas et al., 1999; Fernandez et al., 1984; Kávási et al., 2010; Vaupotič, 2008) and the second that of radon as a tracer for air movement within a cave (Cunningham and Larock, 1991; Hakl et al., 1996; Kies and Massen, 1997; Kowalczk and Froelich, 2010; Perrier et al., 2004; Przylibski, 1999). Minute quantities of uranium $\left({ }^{238} \mathrm{U}\right)$ present in limestone result in relatively high values of radon in karstic caves (Cigna, 2005; Gillmore et al., 2002; Hakl et al., 1997) due to the low natural ventilation of the underground cavities. Tectonic faults constitute an additional source of radon (Ball et al., 1991; Gillmore et al., 2000; Šebela et al., 2010). Variations of radon concentration in cave air arise from a balance of the emission from cave surfaces and drip waters, decay in cave air, and exchange with the outside atmosphere (Wilkening and Watkins, 1976). Seasonal changes in natural ventilation often cause large temporal variation in radon levels, most commonly characterised by high summer and low winter concentrations (Kowalczk and Froelich, 2010; Perrier and Richon, 2010; Przylibski, 1999; Tanahara et al., 1997; Wilkening and Watkins, 1976). However, other atypical patterns have also been documented, such as maximum concentrations during autumn and minimum during summer in Mammoth Cave, Kentucky (Eheman et al., 1991) or in Moestroff Cave (Luxembourg), where the lowest concentrations are observed in the summer (Kies and Massen, 1997). As a result of elevated radon concentrations, Postojna Cave as well has been under permanent radon survey since 1995 (Vaupotič et al., 2001; Vaupotič, 2008). In this study, radon was monitored in the Great Mountain hall of the Postojna Cave from July 2005 to October 2009. Our intention was to establish a model of radon concentration in the cave air on the basis of temperature differences between the cave air and the outside air. Such a model could reduce the number of measurements in the cave needed for dose estimates for the personnel working there. 

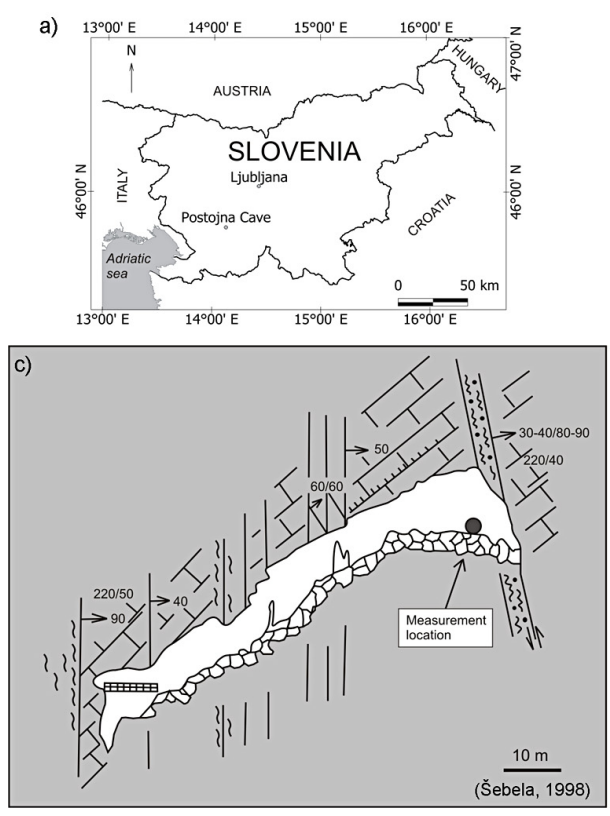

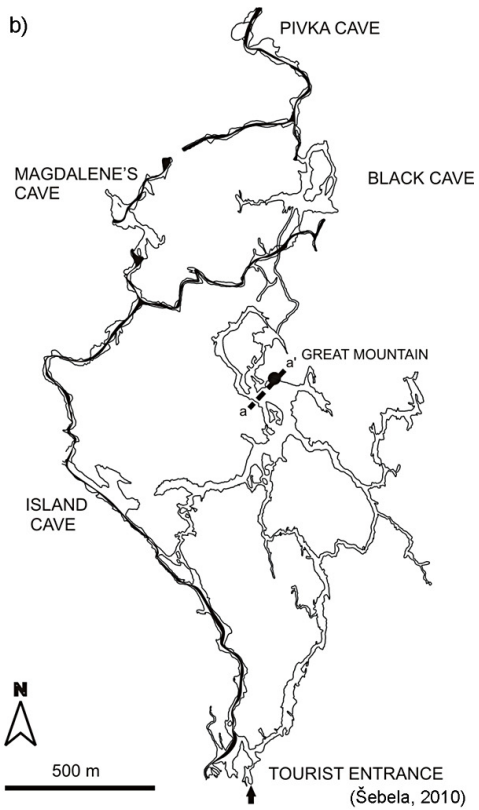

Fig. 1. (a) Slovenia with the Postojna Cave indicated. (b) The passages of Postojna Cave with the monitoring site in the Great Mountain hall and the cross section $\mathrm{a}-\mathrm{a}^{\prime}$ indicated. (c) Cross section of the Great Mountain hall with the measurement point and tectonic structure.

\section{Site description}

Postojna Cave, with $20 \mathrm{~km}$ of galleries, is the longest known cave system and the largest of 21 show caves in Slovenia (Fig. 1a). It is one of the most visited show caves in the world. The vertical extent of the system is $115 \mathrm{~m}$. The height above sea level of the river Pivka where it enters the cave is $511 \mathrm{~m}$ and that of the platform in front of the cave entrance $529 \mathrm{~m}$. The cave passages have been developed in approximately $800 \mathrm{~m}$ of Upper Cretaceous bedded limestone situated between two important Dinaric faults (Šebela et al., 2010). This cave is a typical horizontal cave (Fig. 1b) (Šebela, 1998) with the tourist entrance being a large natural entrance with a diameter of several meters. An electric train takes visitors through $2 \mathrm{~km}$ long galleries and passages to the station in the cave, from where they start a walking route. Besides the part of the cave open to visitors, the Postojna Cave system is composed of several halls, named Island Cave, Magdalene's Cave and Black Cave, connected to each other by narrow passages. Some of them can be accessed from the surface through their own entrances (Fig. 1b). There is no forced ventilation in the cave and air is exchanged only by natural air draught through the numerous cracks, corridors and breathing halls (Gams, 1974) connecting the cave with the outside atmosphere. The measurement site is located in the Great Mountain hall (Fig. 1c), which is the biggest collapse chamber in Postojna Cave and lies about $2 \mathrm{~km}$ from the tourist entrance.

\section{Methodology}

\subsection{Measurement methods}

Radon was monitored continuously in the Great Mountain hall from July 2005 to October 2009. During the first year, a Barasol probe (MC-450, ALGADE, France) was used, which was then replaced by a Radim 5 WP monitor (SMM Company, Prague, Czech Republic). Data for some months in 2006, at the end of 2007, and in summer 2009 are missing because of high air humidity, which damaged the measuring devices. The Barasol probe is designed primarily for radon measurements in soil gas. The probe gives radon concentration, based on alpha spectrometry of radon decay products in the energy range of $1.5 \mathrm{MeV}$ to $6 \mathrm{MeV}$ using an implanted silicon detector. The detector sensitivity is $50 \mathrm{~Bq} \mathrm{~m}^{-3}$ and a sampling frequency was set at once an hour. In addition to radon concentration, the probe also recorded temperature and barometric pressure. The Radim 5 monitor determines radon concentration by measuring gross alpha activity of the decay products ${ }^{218} \mathrm{Po}$ and ${ }^{214} \mathrm{Po}$, collected electrostatically on the surface of a semiconductor detector. The sensitivity is about $50 \mathrm{~Bq} \mathrm{~m}^{-3}$ and the sampling frequency was twice an hour. The data have been stored in the internal memory of both instruments and then transferred to a personal computer for further evaluation. The daily averages of radon concentration were calculated from raw measurements.

Hourly values and daily averages of outside air temperature at the Postojna meteorological station were obtained from the Office of Meteorology of the Environmental Agency of the Republic of Slovenia. 


\subsection{Radon modelling}

Fluctuations in cave air radon concentration are a balance between the net exhalation of radon from the surfaces within the cave, decay in cave air, and the degree of mixing of outside air with cave air (Wilkening and Watkins, 1976) as described by mass balance Eq. (1):

$\frac{\mathrm{d} C_{\text {cave }}}{\mathrm{d} t}=E_{\mathrm{Rn}} \frac{S}{V}-\lambda C_{\text {cave }}-\frac{Q}{V}\left(C_{\text {cave }}-C_{\text {out }}\right)$

where $C_{\text {cave }}$ and $C_{\text {out }}$ represent radon concentration in the cave and outside, $E_{\mathrm{Rn}}$ is a net flux of radon atoms from the material surrounding the cavity into the open volume, $S$ and $V$ are surface area and volume of the cavity, $\lambda$ is the radon decay constant and $Q$ the natural flow rate of cave air. Since the exact volume of the cave and the natural flow rate are not known because of the complex morphology of the Postojna cave passages, radon mass balance Eq. (1) can be simplified to Eq. (2),

$\frac{\mathrm{d} C_{\text {cave }}}{\mathrm{d} t} \approx \Phi-\lambda C_{\text {cave }}-\frac{k_{i}|\Delta T| C_{\text {cave }}}{L}$

where $\Phi\left(\mathrm{Bq} \mathrm{m}^{-3} \mathrm{~s}^{-1}\right)$ is the radon source term, $\Delta T(\mathrm{~K})$ is the difference between outside and cave temperatures, $L(\mathrm{~m})$ is distance of the measuring location from the entrance and $t$ (s) is time. The outside radon concentration is set at zero, since it is much less than the value in the cave. The radon source term, $\Phi$, is calculated from Eq. (3) in the case of no ventilation, when radon concentration reaches its maximum

$\Phi=\lambda C_{\text {cave }}^{\max }$

Values of $k$ can be calculated from existing data for every single day according to Eq. (4),

$k_{i}=\frac{\Phi L}{|\Delta T| C_{n}}-\frac{\lambda L}{|\Delta T|}-\frac{\left(C_{n+1}-C_{n}\right) L}{\mathrm{~d} t|\Delta T| C_{n}} \quad\left[\mathrm{~ms}^{-1} \mathrm{~K}^{-1}\right]$

where $C_{n}$ and $C_{n+1}$ represent average daily radon concentrations for two consecutive days and $\mathrm{d} t$ is 1 day.

\section{Results and discussion}

Radon concentration in the Great Mountain hall was found to be in the range from about $200 \mathrm{~Bq} \mathrm{~m}^{-3}$ to about $3 \mathrm{kBq} \mathrm{m}^{-3}$. The lowest average monthly radon concentration between 2005 and 2009 occurred in March $\left(600 \mathrm{~Bq} \mathrm{~m}^{-3}\right)$ and the highest in June $\left(2500 \mathrm{~Bq} \mathrm{~m}^{-3}\right)$ (Fig. 2). The seasonal pattern is mainly the result of air movements caused by differences between external and internal air densities, controlled to a large extent by air temperature; this corresponds well with the processes characteristics of horizontal caves (Hakl et al., 1996). The cave temperature varies from 9 to $10^{\circ} \mathrm{C}$ only, the whole year round. Radon concentrations can vary substantially from place to place in the cave (Kobal et al., 1987, 1988), depending on the distance from the entrance,

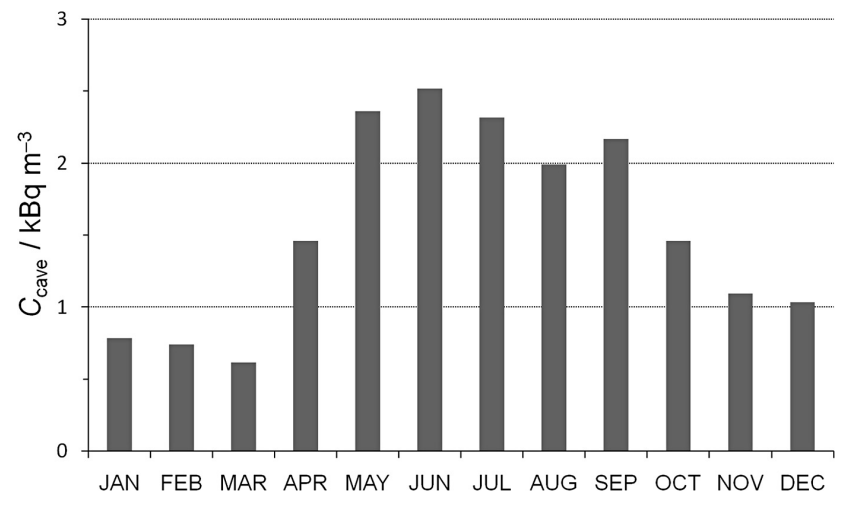

Fig. 2. Average monthly radon concentrations in the Great Mountain hall from 2005 to 2009.

the shapes of the various halls and corridors and the presence of vertical cracks and breathing halls that affect the ventilation of the cave. In addition to seasonal variation, diurnal variations were also observed at some points in the cave, usually in summer (Kobal et al., 1988; Vaupotič, 2008). However, this is not the case in the Great Mountain hall, presumably because of its huge volume; it is open on all sides and thus intensively aerated. This has a smoothing effect on radon concentration and thus reduces its diurnal variation.

\subsection{Cave air ventilation and seasonal radon behaviour}

During the cold winter months, air temperature in the cave is higher than outside and this temperature difference causes a natural draught of less dense, radon-rich cave air upwards through vertical cracks and channels into the outside atmosphere, thus allowing the entry of cold denser outside air into the cave through the tourist entrance (chimney effect). This continuous ventilation significantly lowers the radon concentration. As can be seen in Fig. 3a, radon concentration and outside temperature follow a linear relationship, with a correlation coefficient $(R)$ of 0.62 , as long as the outside temperature is lower than the cave temperature. However, when the daily outside temperature drops below $-6^{\circ} \mathrm{C}$, radon concentration increases, presumably due to ice and snow covering the smaller breathing holes from above, thus preventing the "chimney" effect. Radon concentration reaches its maximum when ventilation stops or is minimal. This happens at outside temperatures approximately the same as the cave temperature $\left(10^{\circ} \mathrm{C}\right)$, as seen in Fig. 3a. Small black dots on Fig. 3a at temperatures above $10^{\circ} \mathrm{C}$ and radon concentrations below $1500 \mathrm{~Bq} \mathrm{~m}^{-3}$, reflect the influence of some other parameters and were not included in the analysis.

The influence of atmospheric changes on radon concentration in the Great Mountain hall was observed only after $114 \mathrm{~h}$. The reason for this time lag is the geomorphology of Postojna Cave and the long distance from the tourist entrance $(2 \mathrm{~km})$. This shifted influence of the outdoor temperature is most clearly noticed in spring (Fig. 4a), when the cross 

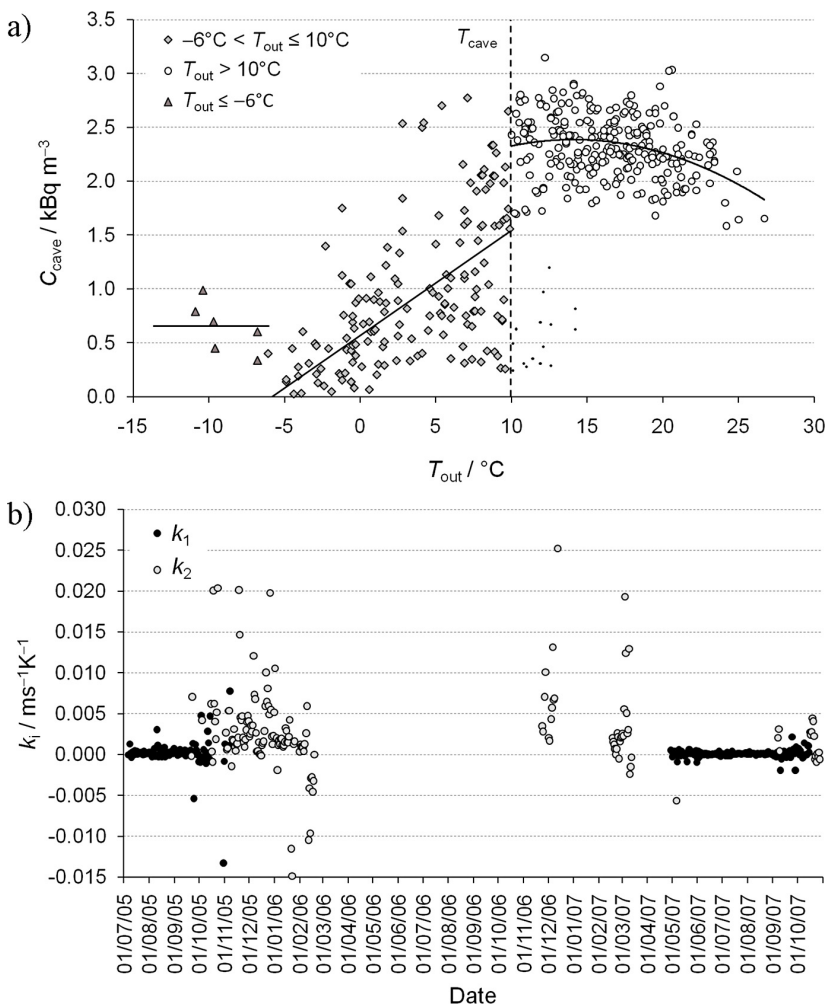

Fig. 3. (a) Correlation between daily average radon concentration $\left(C_{\text {cave }}\right)$ in the Great Mountain hall and daily average outside air temperature ( $\left.T_{\text {out }}\right)$ with a time lag of 4 days between temperature and radon concentration. (b) Calculated values of $k_{1}$ and $k_{2}$ for the period from July 2005 to October 2007.

correlation between radon concentration and outside air temperatures points to $114 \mathrm{~h}$ lag time (Fig. 5)

In summer the ventilation is reversed and air flows from higher to lower openings of the cave. The temperature difference between outside air and cave air creates a pressure difference which causes a draught of air out of the cave and consequently lower radon concentrations over time (Fig. 3a). However this process is observed in the Great Mountain hall only when the temperature difference between outside and cave air is high enough. The effect of lowering the radon concentration could be observed during two periods of hot summer days with average daily temperatures above $20^{\circ} \mathrm{C}$ in July and August 2008 (Fig. 4b).

The transition periods in spring and autumn are characterised by a large range of ventilation rates caused by diurnal variability in the temperature difference between cave and outside air. In spring, radon concentration rises only after some days of higher daily temperatures (Fig. 4a), since the increased ventilation during the cold nights prevents the accumulation of radon in the cave air. On the other hand, a sudden drop in radon concentration below $500 \mathrm{~Bq} \mathrm{~m}^{-3}$ can be observed as soon as one or two days after the first cold front on 19 November 2008 (Fig. 4c).

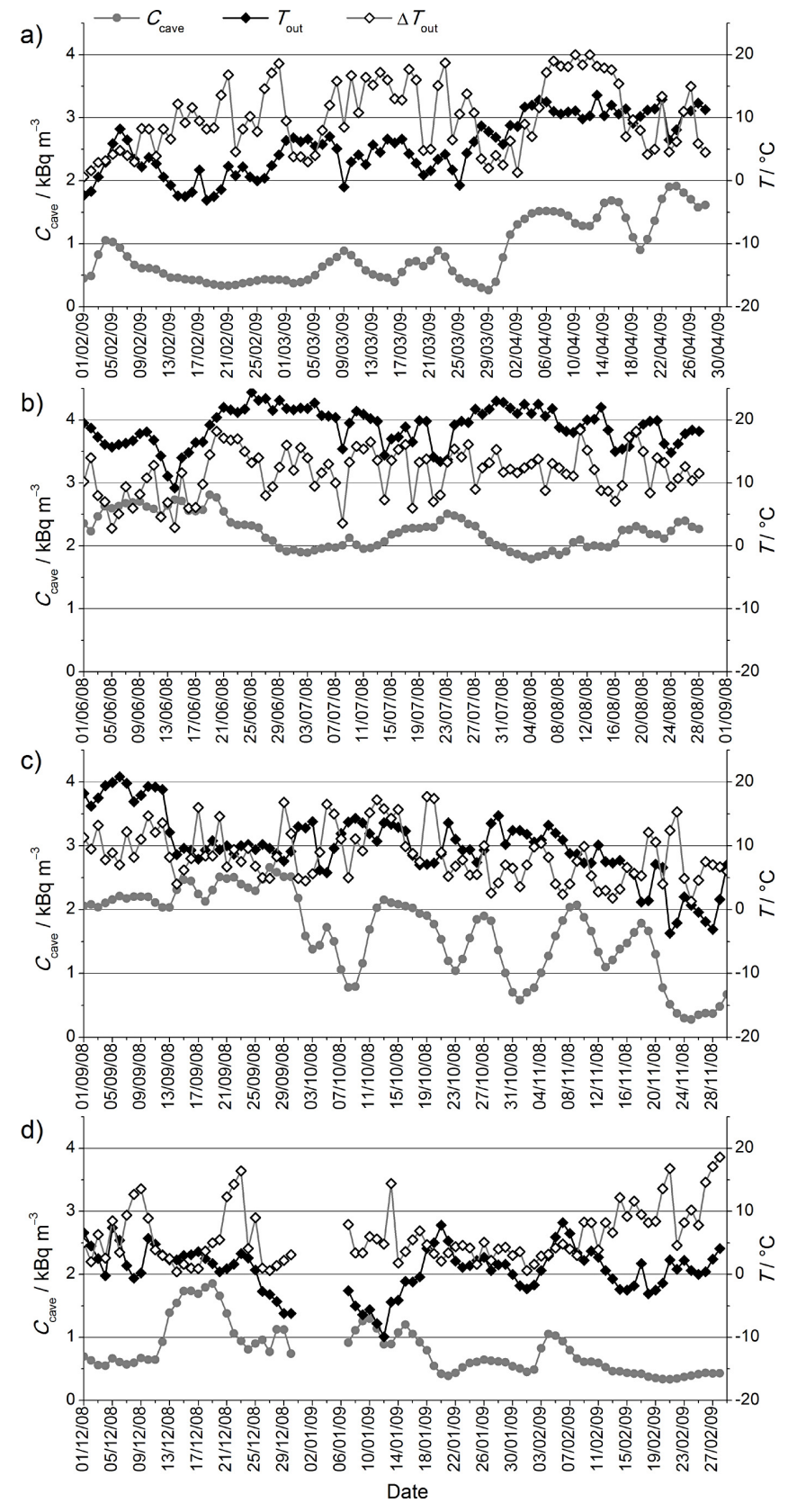

Fig. 4. Average daily radon concentrations ( $\left.C_{\text {cave }}\right)$, average daily outside temperatures ( $\left.T_{\text {out }}\right)$ and the difference between maximum and minimum outside temperatures ( $\left.\Delta T_{\text {out }}\right)$ for different seasons: (a) winter/spring 2009 (February, March, April), (b) summer 2008 (June, July, August), (c) autumn 2008 (September, October, November) and (d) winter 2008/2009 (December, January, February).

In winter, with constantly low outside temperatures (14 to 18 December 2008, Fig. 4d), continuous ventilation leads to low radon levels in the cave. In contrast, the effect of decreasing ventilation can be observed during the sunny days from 8 to 12 December 2008 (Fig. 4d), characterised by 


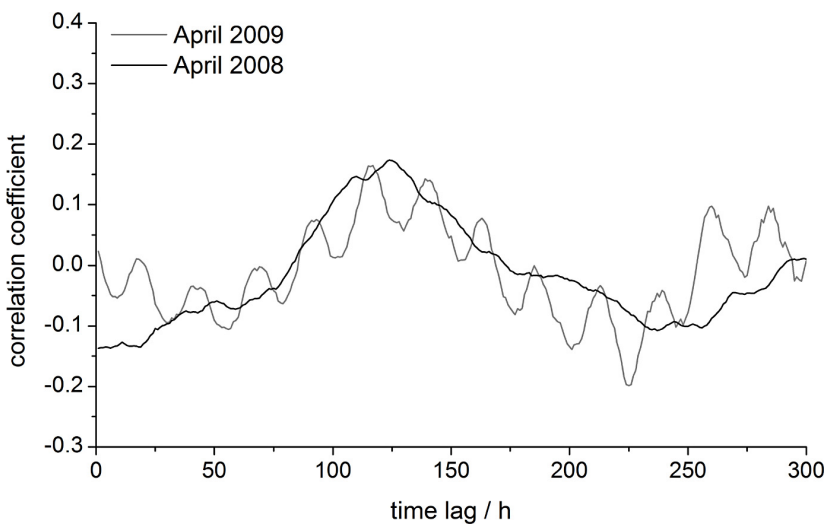

Fig. 5. Cross correlation between radon concentration and outside temperature in the period of April 2008 and April 2009 shows a common maximum at a time lag of $114 \mathrm{~h}$.

high daytime temperatures around $10^{\circ} \mathrm{C}$, which caused the ventilation to slow down during daytime, thus allowing radon accumulation in the cave.

\subsection{Radon modelling}

The radon concentration measured from July 2005 to October 2007 was used to establish a model, while the other part of the dataset (November 2007 to November 2009) was used for testing the model. The radon source term, calculated from Eq. (3), is $(5.9 \pm 0.6) \times 10^{-3} \mathrm{~Bq} \mathrm{~m}^{-3} \mathrm{~s}^{-1}$ in the case of no ventilation, when radon concentration reaches its maximum at the confidence level of $97.5 \%$ $\left(\mathrm{C}_{\mathrm{cave}}^{\max }=2800 \pm 280 \mathrm{~Bq} \mathrm{~m}^{-3}\right)$. For this purpose, the time shift of 4 days between outside temperature and radon concentration was taken into account.

Constant $k$ was calculated for every $T_{\text {out }}-C_{\text {cave }}$ pair (daily averages) in the period from July 2005 to October 2007 and average values were determined separately for summer and winter, according to different ventilation regimes (Fig. 3b). Taking into account the different behaviour of radon concentration at temperatures below $-6^{\circ} \mathrm{C}$ (Fig. 3a), the average radon concentration of $0.64 \pm 0.23 \mathrm{kBq} \mathrm{m}^{-3}$ was calculated. The results are collected in Table 1. Average $k$ values were used for predicting radon concentration using Eq. (2) according to the rules described in Table 1 . Constant $k_{1}$ was used for days with an average daily temperature above $10^{\circ} \mathrm{C}$ and $k_{2}$ for days with an average daily temperature between -6 and $10^{\circ} \mathrm{C}$. When the average daily temperature dropped below $-6^{\circ} \mathrm{C}$, radon concentration was set to $0.64 \mathrm{kBq} \mathrm{m}^{-3}$ (Table 1). The time series of predicted and measured radon concentrations are presented in Fig. 6. Radon concentration is more stable in summer than in winter (Fig. 3b), causing a higher dispersion of $k_{2}$ values and eventually also a larger discrepancy between measured and predicted radon concentrations in winter.
Table 1. Average values of $k$ for summer $\left(k_{1}\right)$ and winter $\left(k_{2}\right)$ and estimated radon concentrations at daily temperatures below $-6{ }^{\circ} \mathrm{C}$.

\begin{tabular}{llcc}
\hline$k_{i}$ & $T_{\text {out }}$ & $k\left(\mathrm{~mm} \mathrm{~s}^{-1} \mathrm{~K}^{-1}\right)$ & $C_{\text {cave }}\left(\mathrm{kBq} \mathrm{m}^{-3}\right)$ \\
\hline$k_{1}$ & $T_{\text {out }}>10^{\circ} \mathrm{C}$ & $0.2 \pm 1.1$ & \\
$k_{2}$ & $-6^{\circ} \mathrm{C}<T_{\text {out }} \leq 10^{\circ} \mathrm{C}$ & $2 \pm 31$ & \\
& $T_{\text {out }}<-6{ }^{\circ} \mathrm{C}$ & & $0.64 \pm 0.23$ \\
\hline
\end{tabular}

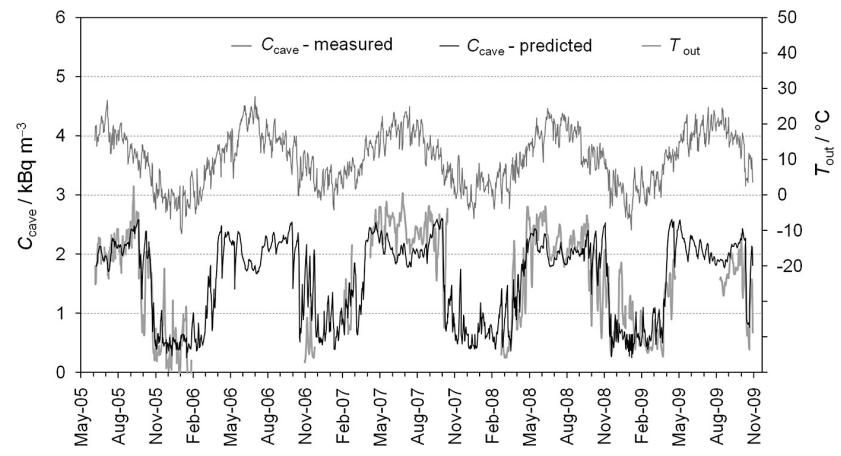

Fig. 6. Comparison of predicted and measured radon concentration $\left(C_{\text {cave }}\right)$ and outside air temperature $\left(T_{\text {out }}\right)$ from July 2005 to October 2009.

The correlation coefficient of 0.76 between measured and predicted radon concentrations on the validation dataset, from November 2007 to October 2009, is high. As expected, the correlation is poorer in the transitional periods of spring and autumn.

\section{Conclusions}

Two major ventilation regimes have been identified in the Postojna Cave that have a direct influence on radon concentration in the cave. In cold periods the cave behaves as a large chimney and the warmer, radon-rich cave air is released to the colder outside atmosphere, driving an inflow of fresh air with low radon levels. Radon levels in the cave are highest when the outside temperature is similar to or lower than the cave temperature $\left(10^{\circ} \mathrm{C}\right)$ and, hence, air movement is very low. Calculations have shown that the effect of the difference between outside and cave temperature on radon concentration was delayed by four days, presumably because of the distance of the Great Mountain from the tourist entrance (ca. $2 \mathrm{~km}$ ). When the daily outside temperature drops below $-6^{\circ} \mathrm{C}$, radon concentration increases. It is assumed that ice and snow on the surface above the cave prevent the cave air from leaving the cave. In summer, the ventilation is minimal or reversed and the air flows from higher to lower openings of the cave. When the temperature difference between cave and outside air is high enough to overcome the barrier 
of the long distance to the cave entrance, the subsequent air pressure difference causes a draught of air out of the cave and consequently lowers radon concentration.

This model, developed on the basis of the results of our previous long-term radon monitoring in Postojna Cave, provides a relatively good prediction of radon concentration in the cave air, simply on the basis of the difference in air temperature between the cave and outside. Although successful, the model will not replace measurements, but could markedly reduce their number without diminishing the level of reliability of data needed for dose estimates for the personnel working in the cave.

Acknowledgements. This study was financed by the Slovenian Research Agency under the contract number J1-0745. The cooperation of the Postojna Cave management and personnel is appreciated.

Edited by: R. Crockett

Reviewed by: two anonymous referees

\section{References}

Ball, T. K., Cameron, D. G., Colman, T. B., and Roberts, P. D.: Behaviour of radon in the geological environment: a review, Q. J. Eng. Geol., 24, 169-182, 1991.

Cigna, A. A.: Radon in caves, Int. J. Speleol., 34, 1-18, 2005.

Cohen, B. L.: Radon daughter exposure to uranium miners, Health Phys., 42, 449-457, 1982.

Cunningham, K. I. and Larock, E. J.: Recognition of microclimate zones through radon mapping, Lechuguilla Cave, Carlsbadcaverns-national-park, New-Mexico, Health Phys., 61, 493-500, 1991.

Duenas, C., Fernandez, M. C., Canete, S., Carretero, J., and Liger, E.: Rn-222 concentrations, natural flow rate and the radiation exposure levels in the Nerja Cave, Atmos. Environ., 33, 501$510,1999$.

Eheman, C., Carson, B., Rifenburg, J., and Hoffman, D.: Occupational exposure to radon daughters in Mammoth-Cave-NationalPark, Health Phys., 60, 831-835, 1991.

Fernandez, P. L., Quindos, L. S., Soto, J., and Villar, E.: Radiation exposure levels in Altamira Cave, Health Phys., 46, 445-447, 1984.

Gams, I.: Concentration of $\mathrm{CO}_{2}$ in the caves in relation to the air circulation (in the case of the Postojna Cave), Acta Carsol., VI, 184-192, 1974.

Gillmore, G. K., Sperrin, M., Phillips, P., and Denman, A.: Radon hazards, geology, and exposure of cave users: A case study and some theoretical perspectives, Ecotoxicol. Environ. Saf., 46, 279-288, 2000.

Gillmore, G. K., Phillips, P. S., Denman, A. R., and Gilbertson, D. D.: Radon in the Creswell Crags Permian limestone caves, J. Environ. Radioactiv., 62, 165-179, 2002.

Hakl, J., Csige, I., Hunyadi, I., Várhegyi, A., and Géczy, G.: Radon transport in fractured porous media - Experimental study in caves, Environ. Int., 22, 433-437, 1996.
Hakl, J., Hunyadi, I., Csige, I., Géczy, G., Lénárt, L., and Várhegyi, A.: Radon transport phenomena studied in Karst caves - international experiences on radon levels and exposures, Radiat. Meas., 28, 675-684, 1997.

Kávási, N., Somlai, J., Szeiler, G., Szabó, B., Schafer, I., and Kovács, T.: Estimation of effective doses to cavers based on radon measurements carried out in seven caves of the Bakony Mountains in Hungary, Radiat. Meas., 45, 1068-1071, 2010.

Kies, A. and Massen, F.: Radon generation and transport in rocks and soil, in: The Moestroff Cave - a study on the geology and climate of Luxemburg's largest Maze Cave, edited by: Massen, F., Centre de Recherche Public - Centre Universitaire, 159-183, 1997.

Kobal, I., Smodiš, B., Burger, J., and Škofljanec, M.: Atmospheric ${ }^{222} \mathrm{Rn}$ in tourist caves of Slovenia, Yugoslavia, Health Phys., 52, 473-479, 1987.

Kobal, I., Ančik, M., and Škofljanec, M.: Variations of ${ }^{222} \mathrm{Rn}$ air concentration in Postojna Cave, Radiat. Prot. Dosim., 25, 207211, 1988.

Kowalczk, A. J. and Froelich, P. N.: Cave air ventilation and $\mathrm{CO}_{2}$ outgassing by radon-222 modeling: How fast do caves breathe?, Earth. Planet. Sci. Lett., 289, 209-219, 2010.

Nazaroff, W. W.: Radon transport from soil to air, Rev. Geophys., 30, 137-160, 1992.

Perrier, F. and Richon, P.: Spatiotemporal variation of radon and carbon dioxide concentrations in an underground quarry: coupled processes of natural ventilation, barometric pumping and internal mixing, J. Environ. Radioactiv., 101, 279-296, 2010.

Perrier, F., Richon, P., Crouzeix, C., Morat, P., and Le Mouel, J. L.: Radon-222 signatures of natural ventilation regimes in an underground quarry, J. Environ. Radioactiv., 71, 17-32, 2004.

Przylibski, T. A.: Radon concentration changes in the air of two caves in Poland, J. Environ. Radioactiv., 45, 81-94, 1999.

Šebela, S.: Tectonic structure of Postojnska jama cave system, ZRC Publishing (Scientific Research Centre), Ljubljana, 112 pp., 1998.

Šebela, S., Vaupotič, J., Koš’ták, B., and Stemberk, J.: Direct measurement of present-day tectonic movement and associated radon flux in Postojna Cave, Slovenia, J. Cave Karst Stud., 72, 21-34, 2010.

Sevc, J., Kunz, E., and Placek, V.: Lung-cancer in uranium miners and long-term exposure to radon daughter products, Health Phys., 30, 433-437, 1976.

Tanahara, A., Taira, H., and Takemura, M.: Radon distribution and the ventilation of a limestone cave on Okinawa, Geochem. J., 31, 49-56, 1997.

Vaupotič, J., Csige, I., Radolić, V., Hunyadi, I., Planinić, J., and Kobal, I.: Methodology of radon monitoring and dose estimates in Postojna Cave, Slovenia, Health Phys., 80, 142-147, 2001.

Vaupotič, J.: Nanosize radon short-lived decay products in the air of the Postojna Cave, Sci. Total Environ., 393, 27-38, 2008.

Wilkening, M. H. and Watkins, D. E.: Air exchange and Rn-222 concentrations in Carlsbad Caverns, Health Phys., 31, 139-145, 1976. 